\title{
Digestion in Ruminants
}

\author{
Barbara Niwińska
}

Additional information is available at the end of the chapter

http://dx.doi.org/10.5772/51574

\section{Introduction}

Ruminants, cloven-hoofed mammals of the order Artiodactyla, obtain their food by browsing or grazing, subsisting on plant material (Hungate, 1966). Today, 193 species of living ruminants exist in 6 families: Antilocapridae, Bovidae, Cervidae, Giraffidae, Moschidae and Tragulidae (Nowak, 1999). The number of wild ruminants is about 75 million and of domesticated about 3.6 billion (Hackmann and Spain, 2010). Approximately 95\% of the population of domesticated ruminants constitute species: cattle, sheep and goats, all of them belong to the Bovidae family. Cattle and sheep are the two most numerous species and cattle is of the most economic importance. The economic value of milk and beef production in the EU is almost 125 billion Euro per year and accounts for $40 \%$ of total agricultural production (FAIP, 2003). The dairy cows is unique among all other mammalian species because of the intense artificial transgenerational genetic selection for milk production during the last 50 $\mathrm{yr}$, so that annual averages of more than $12,500 \mathrm{~kg} / \mathrm{cow}$ of milk per lactation are not uncommon (Eastridge, 2006). The selection has increased their peak energy yield by about $250 \%$ (20 Mcal $\times \mathrm{d}^{-1}$ observed vs. $7.76 \mathrm{Mcal} \times \mathrm{d}^{-1}$ expected) (Hackmann and Spain, 2010). Genetic improvement is accompanied by increasing metabolic demands for energy. The efficient use of energy of the feed resources is the main reason for the numerous and multilateral studies on carbohydrates digestion processes in cattle.

\section{Digestive tract}

Ruminants digestive system is characterized by functional and anatomical adaptations that allowed them to unlock otherwise unavailable food energy in fibrous plant material, mainly in cellulose and others recalcitrant carbohydrates (Van Soest, 1994). This property gives them an advantage over nonruminants. An important characteristic of ruminants digestive system is the occurrence of the microbial fermentation prior to the gastric and intestinal digestion activity. Their unique digestive system integrates a large microbial population 
with the animal's own system in the symbiotic relationship. The microbial fermentation occurs mainly in the rumen, the first chamber of the four-compartment stomach, which consists also of the reticulum and omasum (act as filters), and the abomasum (the true enzymatic stomach).

\section{Rumen function}

The feedstuffs consumed by ruminants are all initially exposed to the fermentative activity in the rumen, the place of more or less complete microbial fermentation of dietary components. Ruminal fermentation initially results in the degradation of carbohydrates and protein to short-term intermediates such as sugars and amino acids. The products of this initial degradation are readily metabolized to microbial mass and carbon dioxide, methane, ammonia and volatile fatty acids (VFA): primarily acetate, propionate and butyrate and to a lesser degree branched chain VFA and occasionally lactate. The rate and extent of fermentation are important parameters that determine protein, vitamins, and short-chain organic acids supply to the animal (Koenig et al., 2003; Hall, 2003). The host ruminant animal absorbs VFA (mostly through the rumen wall) and digests proteins, lipids, and carbohydrate constituents of microbes and feed residues entering the small intestine to supply its maintenance needs and for the production of meat and milk. Ruminant animals derive about $70 \%$ of their metabolic energy from microbial fermentation of feed particles and microbial protein accounts for as much as $90 \%$ of the amino acids reaching the small intestine (Nocek and Russell, 1988; Bergman, 1990).

The rumen has a complex environment composed of microbes, feed at various stages of digestion, gases, and rumen fluid. Rumen microorganisms usually adhere to feed particles and form biofilms to degrades plant material. The efficiency of ruminants to utilize of feeds is due to highly diversified rumen microbial ecosystem consisting of bacteria $\left(10^{10}-10^{11}\right.$ cells $/ \mathrm{ml}$, more than 50 genera), ciliate protozoa $\left(10^{4}-10^{6} / \mathrm{ml}, 25\right.$ genera), anaerobic fungi $\left(10^{3}-\right.$ $10^{5}$ zoospores $/ \mathrm{ml}, 5$ genera) and bacteriophages $\left(10^{8}-10^{9} / \mathrm{ml}\right)$ (Hobson, 1989). The synergism and antagonism among the different groups of microbes is so diverse and complicated that it is difficult to quantify the role played by any particular group of microbes present in the rumen (Kamra, 2005). Bacterial numbers in the rumen are the highest and bacteria play a dominant role in all facets of ruminal fermentation. They are adopted to live at acidities between $\mathrm{pH} 5.5$ and 7.0, in the absence of oxygen, at the temperature of $39-40^{\circ} \mathrm{C}$, in the presence of moderate concentration of fermentation products, and at the expense of the ingesta provided by ruminant (Hungate, 1966). Rumen digesta volume accounts for 8-14\% of body weight of cows and is characterized by dry matter content about $15 \%$ (Dado and Allen, 1995; Reynolds et al., 2004; Kamra, 2005).

\section{Techniques for estimating rumen digestibility}

The rumen digestibility of feeds can be estimated by biological methods. The "basic model" which gives the value utilized for defining the nutritive value of a feed is the in vivo digestibility, which represents the entire process occurring in the gastro-intestinal tract. In 
vitro methods which simulate the digestion process, have being less expensive and less timeconsuming, and they allow to maintain experimental conditions more precisely than do in vivo trials. Three major in vitro digestion techniques currently available to determine the nutritive value of ruminant feeds are: digestion with rumen microorganisms (Tilley and Terry, 1963; Menke et al., 1979), digestion with enzymes (De Boever et al., 1986), and in situ the nylon bag technique (Mehrez and Ørskov, 1977). The nylon bag technique (in sacco) has been used for many years to provide estimates of both the rate and the extent of disappearance of feed constituents. Those characteristics are measured by placing feedstuffs in fabric bag and then incubating the bag by certain time intervals in the rumen of animal. However, the single technique does not provide accurate estimation of in vivo digestion. Judkins et al. (1990) compared 11 techniques for estimating diet dry matter digestibility across six different diets in experiment with rams. Authors found, that the rumen digestibility of feeds nutrients was influenced by diets composition, feeding conditions and physiological status of animals. It therefore seems appropriate that the developments and use of various modification of mentioned experimental techniques have enabled much progress in rumen studies.

\section{Carbohydrates classification in ruminants feeds}

Carbohydrates constitute the highest proportion of diets and are important for meeting the energy needs of animals and of rumen microbes, and are important for maintaining the health of the gastrointestinal tract. Typically, carbohydrates make up 70 to $80 \%$ of the diets fed to dairy cattle and are composed of mixture of numerous monomers and polymers (Nocek and Russell, 1988). The carbohydrates fraction of feeds are defined according the chemical or enzymatic methods used for their analysis and availability to the ruminants. Broadly, carbohydrates are classified as nonstructural that are found inside the cells of plants or structural that are found in plant cell walls, but these fractions are not chemically uniform (Van Soest et al., 1991).

Fraction of nonstructural carbohydrates (NSC) includes organic acid, mono- di- and oligosaccharides, starches, and other reserve carbohydrates. Total NSC includes pectin is referred as nonfibrous carbohydrates (NFC), calculated as 100-(CP+ether extract+ash+NDF) (Mertens, 1992). NFC are the highly digestible and are the major source of energy for high producing cattle. Fraction of structural carbohydrates is characterized by neutral detergent fiber (NDF) and acid detergent fiber (ADF) contents. NDF includes the crosslinked matrix of the plant cell wall with cellulose, hemicellulose, and lignin as the major components and ADF does not include hemicelluloses (Van Soest, 1963). NDF, ADF, and cellulose content are measured according to methods described by Van Soest et al. (1991). The content of hemicellulose was calculated as NDF - ADF (Mertens, 1992).

Fractions of carbohydrates described above are subdivided by chemical composition, physical characteristics, ruminal degradation, and postruminal digestibility characteristics, because of these factors, various modifications of the analytical methods have been proposed (Hall et al., 1999; Nie et al., 2009). 


\section{Degradation and utilization of carbohydrates by rumen microbial ecosystem}

Dietary carbohydrates are the main rumen microbial fermentation substrates. Microbial yields are related primarily to the growth rate that carbohydrate permits. The individual carbohydrates characterized by faster rumen degradation rates result in greater microbial yield (Hall and Herejk, 2001). The enzyme systems produced by microorganisms for carbohydrates hydrolysis are complex; they usually comprise hydrolases from several families, and there may be multiple enzymes hydrolysing each polysaccharide. Nearly all carbohydrate digestion occurs $(>90 \%)$ within the rumen, but under certain circumstances (e.g., high rate of passage), a significant amount of carbohydrate digestion can occur in the small and large intestine.

\section{Nonfibrous carbohydrates}

Nonfiber carbohydrates may provide 30 to $45 \%$ of the diet on a dry matter basis (Hall et al., 2010). The NFC fraction is considered a source of readily available energy for microbial growth (Ariza et al., 2001).

\subsection{Mono- di- and oligosaccharides}

The concentration of monosaccharides, glucose and fructose was estimated from 1\% to 3\% (in grasses and herbage) and of sucrose from $2 \%$ to $8 \%$ (Smith, 1973). Sucrose formed from $\alpha$-D-glucose and $\beta$-d-fructose linked by 1, 2 glycosidic linkage is digested by enzyme sucrose phosphorylase (EC 2.4.1.7, according to the IUB-MB enzyme nomenclature; StanGlasek et al., 2010). Maltose formed from two units of glucose joined with an $\alpha(1-4)$ bond is digested by enzyme $\alpha$-glucosidase (EC 3.2.1.20). Oligosaccharides concentration in the different plants ranges between $0.3 \%$ and $6 \%$ and represent a wide diversity of biomolecules (including stachyose and raffinose), they are chains of monosaccharides that are two to approximately 20 units long. The enzymes belonging to the group of polysaccharide hydrolases (EC 3.2.1.-) which hydrolyse the glycosidic bond between two or more carbohydrates utilize oligosaccharides (Courtois, 2009).

Mono-and disaccharidesare rapidly fermented within the rumen to yield VFA. The rate of glucose fermentation after glucose dosing varied from 422 to $738 \% \mathrm{~h}^{-1}$ and the rate of fermentation of monosaccharides originating from disaccharide hydrolysis was 300 to $700 \%$ $\mathrm{h}^{-1}$ (Wejsberg et al., 1998).

Ruminal bacteria that ferment sucrose include Streptococcus bovis, Lachnospira multiparus, Lactobacillus ruminis, Lactobacillus vitulinis, Clostridium longisporum, Eubacterium cellulosolvens, and some strains of Eubacterium ruminantium, Butyrivibrio fibrisolvens, Ruminococcus albus, Ruminococcus flavefaciens, Megaspaera elsdenii, Prevotella spp., Selenomonas ruminantium, Pseudobutyrivibrio ruminis strain A and Succinivibrio dextrinosolvens (Stewart et al., 1997, Martin and Russell, 1987, Stan-Glasek et al., 2010). Maltose utilize Ruminobacter amylophilus) 
and oligosaccharides Actinomyces ruminicola as a sources of energy (Anderson, 1995; An et al., 2006).

\subsection{Pectic substances}

Pectic substances are a group of galacturonan polymers with neutral sugars (largely arabinose and galactose) substitutions (Jung, 1997). Pectic substances are found in the middle lamella and other cell wall layers (Van Soest, 1994). The most important pectinolytic activity represents pectin lyase (EC 4.2.2.10) (Wojciechowicz, 1982).

Grasses contain from 3 to $4 \%$ of pectin in the dry matter, leguminous plants from 5 to $12 \%$, and sugar beet pulp 25\% (Aspinall, 1970; Van Soest, 1983; Cassida et al., 2007). The utilization of pectin varied from 79.4 to $95.9 \%$ (Marounek and Duškovă, 1999). Most of pectin degrades at a rate of $13 \% \mathrm{~h}^{-1}$ (Hall et al., 1998).

Pectin-utilizing bacteria include Butyrivibrio fibrisolvens and Prevotella ssp.(the principal rumen pectin-utilizing bacteria) and Fibrobacter succinogenes, S. bovis and Lachnospira multiparus (Czerkawski and Breckenridge, 1969; Gradel and Dehority, 1972; Baldwin and Allison, 1983). Pectin is reported to ferment primarily to acetate (Czerkawski and Breckenridge, 1969; Marounek and Duškovă, 1999).

\subsection{Starch}

Starch is a complex of two structurally distinct polymers: amylose and amylopectin (Chesson, 1997). Amylose is chemically composed of $\alpha-1,4$ - linked polymers of glucose. It is degraded by $\alpha$-amylases (EC 3.2.1.1), which releases oligosaccharides maltodextrins, and $\beta$ amylases (EC 3.2.1.2), which remove maltose units. Amylopectin is a highly branched molecule of $\alpha-1,4$ - linked polymers of glucose joined 1,6 at intervals along the backbone moleculr. Amylopectin is degraded to maltose by $\beta$-amylases action (in $50 \%$ ), glucanohydrolases (EC 3.2.1.3 and EC 3.2.1.41) and isoamylase (EC 3.2.1.68). Maltose and maltodextrins are degraded to glucose by $\alpha$-glucosidase (EC 3.2.1.20) (Hobson, 1989). Starch can be degraded by ruminal microbial enzymes as well as enzymes in the small intestine of the ruminats.

Of the nonfibrous fraction, starches are the highest proportion in the diet, and cereal grains is the major source of starch in ruminants diet. The cereal grains differ in their starch content, with wheat containing (on dry matter basis) $77 \%$ starch, corn $72 \%$, and barley and oats 57 to $58 \%$ (Huntington, 1997). Differences exist among cereal grains in their extents and rates of ruminal starch degradation. In the rumen has been digested from 55 to $70 \%$ of corn starch, 80 to $90 \%$ of barley and wheat starch, and 92 to $94 \%$ of oats starch (Huntington, 1997). The degradation rates is estimated from 4.0 to $6.4 \% \mathrm{~h}^{-1}$ for corn starch and from 14.7 to $24.5 \% \mathrm{~h}^{-1}$ for barley starch (Herrera-Saldana et al., 1990; Tamminga et al., 1990). On average, 5 to $20 \%$ of starch consumed is digested postruminally, mainly in the small intestine (from 45 to $85 \%$ of starch entering the duodenum), this capacity is limited by the supply of pancreatic amylase (Hunhington, 1997). 
The bacteria Ruminobacter amylophilus, Prevotela ruminicola, Streptococcus bovis, Succinimonas amylolytica and many strains of Selenomonas ruminantium, Butyrivibrio fibrisolvens, Eubacterium ruminantium and Clostridium ssp., all of the entodiniomorph protozoa and the chytrid fungi are amylolitic (Chesson, 1997). The high-starch concentrate diets favor the development of propionate producing bacteria species (Ørskov, 1986; France and Dijkstra, 2005). The fermentation of starch in the rumen depending on factors such as structure (amylose/amylopectin ratio), plant source, mechanical alterations (grain processing, chewing), diet composition, amount of feed consumed per unit time and degree of adaptation of ruminal microbiota to the diet (Piva and Masoero, 1996, Huntington, 1997; Eastridge, 2006).

\section{Structural carbohydrates}

Structural carbohydrates is less digestible than NFC and is negatively correlated with energy concentration in the diet for ruminants, but is important for rumination, saliva flow, ruminal buffering, and health of the rumen wall, however, high dietary concentrations can limit dry matter intake by increased rumen fill. The retention time of plant fiber in the rumen is sufficiently long ( $48 \mathrm{~h}$ or more in some species) to allow the growth of a fibrolytic microbial population whose extensive fiber utilization contributes a major portion of the energy for the animal (Van Soest, 1994). The cellulose fibers are embedded in a matrix of other structural biopolymers, primarily hemicelluloses and lignin (Lynd, 1999; Marchessault and Sundararajan, 1993; Van Soest, 1994). The high-fibre forage diets encourage the grown of acetate producing bacterial species, the acetate : propionate : butyrate molar proportion would typically be in region 70:20:10 (France and Dijkstra, 2005). Fiber digestion may be reduced due to decreased rumen $\mathrm{pH}$ (the fiber digesters are most active at a $\mathrm{pH}$ of 6.2 to 6.8), and the availability of surface area for colonization (Sutton et al., 1987; Chesson and Forsberg, 1997). Fungi plays an active and positive role in fiber degradation (Williams and Orpin, 1987).

\subsection{Cellulose}

Cellulose content is in the range from 35 to $50 \%$ of plant dry weight (Lynd et al., 1999). It is chemically composed of a homogenous polymers of $\beta$-1,4-D-glucose linked through $\beta-1,4-$ glycosidic bonds. Native cellulose exists as fibrils which are composed of amorphous and crystalline regions formed from cellulose chains, each of them contains between 500 and 14,000 b-1,4D-glucose units (Bazooyar et al., 1012). The digestion of cellulose necessitates a combination of many classes of cellulases. The digestion process including activity of endoglucanases (EC 3.2.1.4), that cut randomly at internal amorphous sites in the cellulose chain; exoglucanases (cellodextrinases EC 3.2.1.74 and cellobiohydrolases EC 3.2.1.91), that act processively on the reducing or non-reducing ends of cellulose chains, releasing either cellobiose or glucose as major products; and glucosidases (EC 3.2.1.21) that hydrolyze soluble cellodextrins and cellobiose to glucose (Lynd et al., 2002). 
Fibrobacter succinogenes, Ruminococcus flavefaciens and $R$. albus are considered to be the predominant cellulolytic bacteria present in the rumens, these species gain selective advantage in the rumen is by optimizing two catabolic activities: cellulose hydrolysis (depolymerization) and efficient utilization of the hydrolytic products (cellodextrins) (Weimer, 1996; Koike and Kobayashi, 2001). F. succinogenes has a potent ability to solubilize crystalline chains of cellulose (Halliwell and Bryant, 1963; Shinkai and Kobayashi, 2007). F. succinogenes produces primarily succinate (a propionate precursor), and lesser amounts of acetate, $R$. flavefaciens produces primarily acetate and lesser amounts of succinate converts to propionate by Selenomonas ruminantium (Weimer at al., 1999).

The predominant ruminal cellulolytic species digest cellulose at rate approximately from 5 to $10 \% \mathrm{~h}^{-1}$, however, the extent to which native cellulose is utilizes by ruminal microorganisms is limiting by the cellulose association with lignin (Weimer, 1996; Chesson, 1993). Cellulose degradability of forages varies from 25 to 90\% (Pigden and Heaney, 1969).

\subsection{Hemicelluloses}

Hemicellulose concentration varies from 6 to $22 \%$ (on dry matter basis) in leaves of grasses and herbs (Schädel at al., 2010). Hemicelluloses are composed of complex heteropolymers that vary considerably in primary composition, substitution and degree of branching, and can be grouped into four classes: xylans, xyloglucans, mannans and mixedlinkage $\beta$-glucans (Ebringerova et al., 2005).

Bacteroides (Fibrobacter) succinogenes, Ruminococcus albus, and Ruminococcus flavefaciens and same strains of Butyrivibrio fibrisolvens and Bacteroides ruminicola are considered to be the organisms responsible for most of the degradation of hemicelluloses (Hespell, 1988). Rumen degradation of hemicelluloses varies from 16 to $90 \%$, depending on their composition (Pigden and Heaney, 1969; Coen and Dehority, 1970).

\subsection{Lignin}

Lignin, a complex phenolic polymer, is indigestible by rumen microbes, but their concentration limits digestibility of structural carbohydrates (Van Soest, 1994). The main reason for reduction of accessibility for the hydrolases secreted by ruminal microbes is the presence of strong covalent bonds between lignin and the cell wall polysaccharides (Chesson, 1993).

\section{Interactions between energy and protein metabolism in rumen}

Manipulation of rumen fermentation through proper diet formulation changes microbial population in a way that improved efficiency of microbial protein synthesis. A major factor in maximizing microbial protein synthesis is the ruminally available energy and $\mathrm{N}$ in the diet. There are many interactions of dietary conditions on bacterial populations and on protein and carbohydrates digestion in rumen. For instance: microbial fermentation releases 
organic acids that readily dissociate to decrease $\mathrm{pH}$ that influence on the microbial ecosystem and determining the selective growth of certain microbial species, and the types and quantities of fermentation products (Russell and Rychlik, 2001).

\section{0. "Synchrony" hypothesis}

The purpose of proper nutrition is "nutritional synchrony" refers to provision of dietary protein ( $\mathrm{N}$ sources, true protein) and energy (ruminally fermented carbohydrates) to the rumen in such a manner that they are available simultaneously in proportions needed by the ruminal microorganisms (Hall and Weimer, 2007). Synchronous nutrient availability should allow more efficient use of nutrients, thus enhancing production of microbial products, increasing nutrient supply to the animal, and potentially improving animal production performance (Sinclair et al., 1993; Hall and Huntington, 2008).

\subsection{Production efficiency}

A number of studies have been conducted to evaluate the effects of "nutritional synchrony" conception on production efficiency, but the results are not consistently. There are many results which confirm increase in the yield of microbial protein when highly degradable carbohydrates were synchronized with rapidly degraded protein (Kovler et al., 1998; Charbonneau et al., 2006). Result from the in sacco study confirms that the better synchronization also affects degradation rate of diet components (Niwinska, 2009; Niwińska and Andrzejewski, 2011). However, nutrient synchrony has generally not resulted in improved animal performance (Yang et al., 2010). The fundamental reason is the following: ruminants animal have the ability to recycle $\mathrm{N}$ from blood and saliva to the gastrointestinal tract during periods of dietary protein deficiency or during periods of asynchronous carbohydrate and protein supply. Hall and Huntington (2008) suggested that for the optimal use of "nutritional synchrony" conception we may need to look at the whole animal, not just the rumen, and that a term such as the optimal balance may be more appropriate when considering the complexity of the ruminant animal.

\subsection{Product composition}

Volatile fatty acids, produced in the rumen, can have a major effect on fat composition of ruminant products. Results of studies with animal models, in tissue culture systems and in clinical research indicate that the functional health-related properties of milk and beef fat appear to be linked to the presence of rumenic acid and vaccenic acid (Parodi, 2005; Lee, 2008; Field et al., 2009). Milk fat provides $30 \%$ of fat consumed by humans and is the richest natural dietary source of those valuable fatty acids (Ritzenthaler et al., 2001). Research undertaken over the past decade has indicated, that concentration of those favorable fatty acids in milk fat may be controlled by the starch/fibre ratio in the diet of dairy cows (Niwińska et al., 2011). 


\subsection{Pollution emissions}

An excessive supply of feed nutrients results in an increase in waste excreted to the environment. The pollutants produced by ruminants are nitrogen and methane, their production is dependent on carbohydrate composition of diet. Improved efficiency of microbial protein synthesis is considered as the most important target in reduction emissions of $\mathrm{N}$, while synchronization of carbohydrate and protein supply in the rumen has been suggested as one possible solution to achieve this aim (Kaswari et al., 2007; Reynolds and Kristensen, 2008; Yang et al., 2010). The rumen microbial ecosystem produces methane as a result of anaerobic fermentation. Methane production results in losses of 5 to $12 \%$ of gross energy of diet and is estimated to be about $15 \%$ of total atmospheric methane emissions (Reid et al., 1980; Moss et al., 2000). The proper selection of carbohydrates in the ration, taking into account the structural and nonfibrous carbohydrates content, can reduce the formation of carbon dioxide, hydrogen and formate the major precursors of methane production in the rumen (Mitsumori and Sun, 2008).

\section{Conclusion}

The current data indicated, that the world production of dairy products is expected to grow $26 \%$ by 2020 and beef production worldwide grew by 30 million tons during 1965-2005 (OECD, 2011; FAO; 2006). The projected increase in cattle production directs our attention to the better utilization of feed resources. Understanding the effects of carbohydrates types and rumen microbial population shifts in response to nutrients contained in different feeds may be valuable to improve production efficiency, to modify the composition of the product and to minimize pollution emissions.

\section{Author details}

Barbara Niwińska

Department of Animal Nutrition and Feed Science,

National Research Institute of Animal Production, Kraków, Poland

\section{References}

An D., Cai S., Dong X. 2006. Actinomyces ruminicola sp. nov., isolated from cattle rumen. Int. J. Sys. Evol. Microbiol. 56:2043-2048.

Anderson K.L. 1995. Biochemical analysis of starch degradation by Ruminobacter amylophilus 70. Appl. Environ. Microbiol., 61:1488-1491.

Ariza P., Bach A., Stern M.D., Hall M.B. 2001. Effects of carbohydrates from citrus pulp and hominy feed on microbial fermentation in continuous culture. J. Anim. Sci. 79:27132718.

Aspinall G.O. 1970. Polysaccharides. Oxford: Pergamon Press.

Baldwin R.L., Allison M.J. 1983. Rumen metabolism. J. Anim. Sci. 57 (Suppl. 2):461-477. 
Bazooyar G., Momany F.A., Bolton K. 2012. Validating empirical force fields for molecularlevel simulation of cellulose dissolution. Comp. Theor. Chem. 984:119-127.

Bergman E.N. 1990. Energy contribution of VFA from the gastrointestinal tract in various species. Physiol. Rev. 70:567-590.

Cassida K.A., Turner K.E., Foster J.G., Hesterman O.B. 2007. Comparison of detergent fiber analysis methods for forages high in pectin. Anim. Feed Sci. Tech. 135:283-295.

Charbonneau E., Chouinard P.Y., Allard G., Lapierre H., Pellerin D. 2006. Milk from forage as affected by carbohydrate source and degradability with alfalfa silage based diets. J. Dairy Sci. 89:283-293.

Chesson A. 1993. Mechanistic model of forage cell wall degradation. In: Rorage cell wall structure and digestibility. Ed: H.G.Jung, D.R.Buxton, R.D. Hatfield, J. Ralph. ASACSSA-SSSA, Madison, WI, pp. 347-376.

Chesson A., Forsberg C.W. 1997. Polysaccharide degradation by rumen microorganism. In: Hobson PN, Stewart CS (eds). The rumen microbial ecosystem. Blackie, London. 329381.

Coen JA. Dehority BA. 1970. Degradation and utilisationof hemicelluloses from intact forage by pure culture of rumen bacteria. Appl. Microbiol. 20:362-368.

Courtois J. 2009. Oligosaccharides from land plants and algae: production and applications in therapeutics and biotechnology. Curr. Opinion Microbiol. 12:261-273.

Czerkawski J.W., Breckenridge G. 1969. Fermentation of various soluble carbohydrates by rumen micro-organisms with particular reference to methane production. Br. J. Nutr. 23:925-937.

Dado R.G., Allen M.S. 1995. Intake limitations, feeding behavior, and rumen function of cows challenged with rumen fill from dietary fiber or inert bulk. J. Dairy Sci. 78:118133.

De Boever J.L., Cottyn B.G., Buysse F.X., Wainman F.W., Vanacker J.M. 1986. The use of an enzymatic technique to predict digestibility, metabolisable and net energy of compound feedstuffs for ruminants. Anim. Feed Sci. Technol. 14:203-214.

Eastridge M.L. 2006. Major advances in applied dairy cattle nutrition. J. Dairy Sci. 89:13111323.

Ebringerova A., Hromadkova Z., Heinze T. 2005. Hemicellulose. Polysaccharides 1: Structure, Characterization and Use. Springer-Verlag, Berlin, pp 1-67.

FAIP. 2003. The economic value of livestock production in the EU 2003. Farm Animal Industrial Platform. AnNe Publishers, ISBN 90-76642-19-2.

FAO 2006. Food and Agriculture Organization. Livestock's Long Shadow. Environmental Issues and Options.

Field C.J., Blewett H.H., Proctor S., Vine D. 2009. Human health benefits of vaccenic acid. Appl. Physiol. Nutr. Metab. 34:979-991.

France J., Dijkstra J. 2005. Volatile fatty acid production. In: J. Dijkstra, J. Forbes, J.M. France (Ed) Quantitative aspects of ruminant digestion and metabolism. $2^{\text {nd }}$ Ed. CAB International, Wallingford, UK, pp.

Gradel C.M., Dehority B.A. 1972. Fermentation of isolated pectin and pectin from intact forages by pure cultures of rumen bacteria. Appl. Microbiol. 23:332-340. 
Hackmann T.J., Spain J.N. 2010. Invited review: Ruminant ecology and evolution: Perspectives useful to ruminant livestock research and production. J. Dairy Sci. 93:13201334.

Hall M.B. 2003. Challenges with nonfiber carbohydrate methods. J. Anim. Sci. 81:3226-3232.

Hall M.B., Herejk C. 2001. Differences in yields of microbial crude protein from in vitro fermentation of carbohydrates. J. Dairy Sci. 84:2486-2493.

Hall M.B., Hoover W.H., Jennings J.P., Webster T.K.M. 1999. A method for partitioning neutral detergent-soluble carbohydrates. J. Sci. Food Agric. 79:2079-2086.

Hall M.B., Huntington G.B. 2008. Nutrient synchrony: Sound in theory, elusive in practice. J. Anim. Sci. 86(E. Suppl.):E287-E292.

Hall M.B., Larson C.C., Wilcox C.J. 2010. Carbohydrate source and protein degradability alter lactation, ruminal, and blood measures. J. Dairy Sci. 93:311-322.

Hall M.B., Pell A.N., Chase L.E. 1998. Characteristics of neutral detergent soluble fiber fermentation by mixed ruminal microbes. Anim. Feed Sci. Technol. 70:23-29.

Hall M.B., Weimer P.J. 2007 Sucrose concentration alters fermentation kinetics, products, and carbon fates during in vitro fermentation with mixed ruminal microbes. J. Animal Sci. 8:1467-1478.

Halliwell G., Bryant M.P. 1963. The cellulolytic activity of pure strains of bacteria from the rumen of cattle. J. Gen. Microbiol. 32:441-448.

Herrera-Saldana R.E., Huber J.T., Poore M.H. 1990. Dry matter, crude protein, and starch degradability of five cereal grains. J. Dairy Sci. 73:2386-2393.

Hespell R.B. 1988. Microbial digestion of hemicelluloses in the rumen. Microbiol. Sci. 5:362365.

Hobson P.N. 1989. The rumen microbial eco-system. Elsevier Applied Science, London, 1989.

Hungate R.E. 1966. The rumen and its microbes. Academic Press Inc. (London) LTD.

Huntington G.B. 1997. Starch utilization by ruminants: From basics to the bunk. J. Anim. Sci. 75:852-867.

IUB-M. Enzyme nomenclature database. International Union of Biochemistry and Molecular Biology, http://enzyme.expasy.org/

Judkins M.B., Krysl L.J., Barton R.K. 1990. Estimating diet digestibility: a comparison of 11 techniques across six different diets fed to rams. J. Anim. Sci. 68:1405-1415.

Jung H.J.G. 1997. Analysis of forage fiber and cell walls in ruminant nutrition. J. Nutr. 127: 810S-813S.

Kamra D.N. 2005. Rumen microbial ekosystem. Curr. Sci. 89:124-135.

Kaswari T., Lebzien P., Flachowsky G., ter Meulen U. 2007. Studies on the relationship between the synchronization index and the microbial protein synthesis in the rumen of dairy cows. Anim. Feed Sci. Technol. 139:1-22.

Koenig K.M., Beauchemin K.A., Rode L.M. 2003. Effect of grain processing and silage on microbial protein synthesis and nutrient digestibility in beef cattle fed barley-based diets. J. Anim. Sci. 81:1057-1067. 
Koike S., Kobayashi Y. 2001. Development and use of competitive PCR assays for the rumen cellulolytic bacteria: Fibrobacter succinogenes, Ruminococcus albus and Ruminococcus flavefaciens. FEMS Microbiol. Lett. 204:361-366.

Kolver E., Muller L.D., Varga G.A., Cassidy T.J. 1998. Synchronization of ruminal degradation of supplemental carbohydrate with pasture nitrogen in lactating dairy cows. J. Dairy Sci. 81:2017-2028.

Lee Y. 2008. Isomer specificity of conjugated linoleic acid (CLA): 9E,11E-CLA. Nutr. Res. Pract. 2:326-330.

Lynd L.R., Weimer P.J., van Zyl W.H., Pretorius I.S. 2002. Microbial cellulose utilization: fundamentals and biotechnology. Microbiol. Mol. Biol. Rev. 66:506-577.

Lynd L.R., Wyman C.E., Gerngross T.U. 1999. Biocommodity engineering. Biotechnol. Prog. 15:777-793.

Marchessault R.H., Sundararajan P.R. 1993. Cellulose, p. 11-95 In G. O. Aspinall (ed.), The polysaccharides, vol. 2. Academic Press, Inc., NewYork, N.Y.

Marounek M., Duškovă D. 1999. Metabolism of pectin in rumen bacteria Butyrivibrio fibrisolvens and Prevotella ruminicola. Lett. Appl. Microbiol. 29:429-433.

Martin S.A., Russel J.B. 1987. Transport and phosphorylation of disaccharides by the ruminal bacterium Streptococcus bovis. Appl. Environ. Microbiol. 53:2388-2393.

Mehrez A.Z., Ørskov E.R. 1977. A study of artificial fibre bag technique for determining the digestibility of feeds in the rumen. J. Agric. Sci. 88:645-650.

Menke K.H., Raab L., Salewski A., Steingass H., Fritz D., Schneider W. 1979. The estimation of the digestibility and metabolisable energy content of ruminant feedingstuffs from the gas production when they are incubated with rumen liquor. J. Agric. Sci. 93:217-222.

Mertens D.R. 1992. Nonstructural and structural carbohydrates. In: Van Horn H.H., Wilcox, C.J. (Eds.), Am. Dairy Sci. Assoc., Champaign, IL, USA. p. 219.

Mitsumori M., Sun W. 2008. Control of Rumen Microbial Fermentation for mitigating Methane Emissions from the Rumen. Asian-Aust. J. Anim. Sci. 21:144-154.

Moss A.R., Jouany J.P.,, Newbold J. 2000. Methane production by ruminants: its contribution to global warming. Ann. Zootech. 49:231-253.

Nie Z., Tremblay G. F., Bélanger G., Berthiaume R., Castonguay Y., Bertrand A., Michaud R., Allard G., Han J. 2009. Near-infrared reflectance spectroscopy prediction of neutral detergent-soluble carbohydrates in timothy and alfalfa. J. Dairy Sci. 92:1702-1711.

Niwińska B. 2009: Effect of carbohydrates in grass silage- based diets on in sacco ruminal degradability of barley grain (Hordeum vulgare L. cv. Lomerit) ground to different particle sizes. Czech J. Anim. Sci. 54: 260-269.

Niwińska B., Andrzejewski M. 2011. Effect of carbohydrates in grass silage-based diets on in sacco ruminal degradability and nutritional value of lupin seeds (Lupinus angustifolius L .cv. Sonet) ground to different particle sizes. Czech J. Anim. Sci. 56: 231-241.

Niwińska B., Bilik K., Andrzejewski M. 2011.Factors influencing rumenic acid and vaccenic acid content in cow's milk fat. Ann. Anim. Sci. 11:3-16.

Nocek J.E., Russell J.B. 1988. Protein and energy as an integrated system: Relationship of ruminal protein and carbohydrate availability to microbial synthesis and milk production. J. Dairy Sci. 71:2070-2107. 
Nowak R.M. 1999. Walker's Mammals of the World. Vol 2. 6th ed. John Hopkins Univ. Press, Baltimore, MD.

OECD-FAO 2011. Organisation for Economic Co-operation and Development-Food and Agriculture Organization. Agricultural Outlook 2011-2020; http://dx.doi.org/10.1787/888932428329.

Ørskov E.R. 1986. Starch digestion and utilization in ruminants. J. Anim. Sci. 63:1624-1633.

Parodi P.W. 2005. Dairy product consumption and the risk of breast cancer. J. Am. Coll. Nutr. 24:S556-S568.

Pigden W.J., Heaney D.P. 1969. Lignocellulose in ruminat nutrition. Adv. Chem. 95:245-261.

Piva G., Masoero F. 1996. Carbohydrates with different ruminal fermentability: starch and fibrous fractions. Zoot. Nutr. Anim. 22:215-229.

Reid J.T., White O.D., Anrique R., Forstin A. 1980. Nutritional energetic of livestock: Some present boundaries of knowledge and future research needs. J. Animal Sci. 51:13931415.

Reynolds C.K., Dürst B., Lupoli B., Humphries D.J., Beever D.E. 2004. Visceral tissue mass and rumen volume in dairy cows during the transition from late gestation to early lactation. J. Dairy Sci. 87:961-971.

Reynolds C.K., Kristensen N.B. 2008. Nitrogen recycling through the gut and the nitrogen economy of ruminants: An asynchronous symbiosis. J. Animal Sci. 86(Suppl.):E293E305.

Ritzenthaler K.L., McGuire M,K., Falen R., Shultz T.D., Dasgupta N., McGuire M.A. 2001. Estimation of conjugated linoleic acid intake by written dietary assessment methodologies underestimates actual intake evaluated by food duplicate methodology. J. Nutr. 131:1548-1554.

Russell J.B., Rychlik J.L. 2001. Factors that alter rumen microbial ecology. Science 292:11191222.

Schädel C., Richter A., Blöchl A., Hoch G. 2010. Hemicellulose concentration and composition in plant cell walls under extreme carbon source-sink imbalances. Physiol. Plantarum 139:241-255.

Shinkai T., Kobayashi Y. 2007. Localization of ruminal cellulolytic bacteria on plant fibrous materials as determined by fluorescence in situ hybridization and Real-Time PCR. Appl. Environ. Microbiol. 73:1646-1652.

Sinclair L.A., Garnsworthy P.C., Newbold J.R., Buttery P.J. 1993. Effect of synchronizing the rate of dietary energy and nitrogen release on rumen fermentation and microbial protein synthesis in sheep. J. Agric. Sci. 120:251-263.

Smith D. 1973. The nonstructural carbohydrates. Chemistry and Biochemistry of Herbage. Ed: G.W. Butler and R. W. Bailey, Academic Press Inc. (London) LTD.

Stan-Glasek K., Kasperowicz A., Guczyńska W., Piknováb M., Pristaš P., Nigutová K., Javorský P., Michałowski T. 2010. Phosphorolytic Cleavage of Sucrose by sucrosegrown ruminal bacterium Pseudobutyrivibrio ruminis strain k3. Folia Microbiol. 55:383385.

Stewart C.S., Flint H.J., Bryant M.P. 1997. The rumen bacteria. The Rumen Microbial Ecosystem. P. N. Hobson and C. S. Stewart, eds. Chapman \& Hall, London, UK. 
Sutton J.D., Bines J.A., Morant S.V., Napper D.J., Givens D.I. 1987. A comparison of starchy and fibrous concentrates for milk production, energy utilization and hay intake by Friesian cows. J. Agric. Sci. (Camb.) 109:375-386.

Tamminga S., Van Vuuren A.M., Van Der Koelen C.J., Ketelaar R.S., Van Der Togt P.L. 1990. Ruminal behavior of structural carbohydrates, non-structural carbohydrates and crude protein from concentrate ingredients in dairy cows. Neth. J. Agric. Sci. 38:513-526.

Tilley J.M.A., Terry R.A. 1963. A two-stage technique for the digestion of forage crops. J. Br. Grassl. Soc. 18:104-111.

Van Soest P.J. 1963. Use of detergents in the analysis of fibrous feeds. I. Preparation of fiber residues of low nitrogen content. J. Assoc. Off. Anal. Chem. 46:825-829.

Van Soest P.J. 1983. Nutritional Ecology of the Ruminant. 2nd edn.Orvallis, OR: O \& B Books.

Van Soest P.J. 1994. Nutritional ecology of the ruminant. $2^{\text {nd }}$. ed. Cornell University Press.

Van Soest P.J., Robertson J.B., Lewis B.A. 1991. Methods for dietary fiber, neutral detergent fiber, and nonstarch polysaccharides in relation to animal nutrition. J. Dairy Sci. 74:3583-3597.

Weimer P.J. 1996. Why don't ruminal bacteria digest cellulose faster? J. Dairy Sci. 79:14961502.

Weimer P.J., Waghorn G.C., Odt C.L., Mertens D.R. 1999. Effect of diet on populations of three species of ruminal cellulolytic bacteria in lactating dairy cows. J. Dairy Sci. 82:122134.

Wejsberg M.R., Hvelplund T., Bibby B.M. 1998. Hydrolysis and fermentation rate of glucose, sucrose and lactose in the rumen. Acta Agric. Scand. A. 48:12-18.

Williams A.G. Orpin C.G. 1987. Polysaccharide degrading enzymes formed by three species of anaerobic fungi grown on a range of carbohydrate substrates. Can. J. Bot. 33:418-426.

Wojciechowicz M., Heinrichova K., Ziolecki A. 1982. An exopectate lyase of Butyrivibrio fibrisolvens from the bovine rumen. J. Gen. Microbiol. 128:2661-2665.

Yang J.Y., Seo J., Kim H.J., Seo S., Ha J.K. 2010. Nutrient Synchrony: Is it a suitable strategy to improve nitrogen utilization and animal performance? Asian-Aust. J. Anim. Sci. 23:972-979. 